\title{
Preparation of pyrochlore-free lead magnesium niobate via adding excess constituent compounds
}

\author{
Chung-Hsin Lu ${ }^{*}$, Shih-Chi Fu \\ Department of Chemical Engineering, National Taiwan University, Taipei, Taiwan, ROC
}

Received 17 October 1995; accepted 26 October 1995

\begin{abstract}
Pyrochlore-free $\mathrm{Pb}\left(\mathrm{Mg}_{1 / 3} \mathrm{Nb}_{2 / 3}\right) \mathrm{O}_{3}$ was successfully synthesized in the mixed-oxide process without using columbite precursors. Adding excess amounts $(5-20 \mathrm{~mol} \%)$ of $\mathrm{MgO}$ and $\mathrm{PbO}$ in starting materials effectively resulted in the complete formation of $\mathrm{Pb}\left(\mathrm{Mg}_{1 / 3} \mathrm{Nb}_{2 / 3}\right) \mathrm{O}_{3}$ after $1000^{\circ} \mathrm{C}$ calcination. The more the excess amount of $\mathrm{MgO}$ was added, the less the minimum excess amount of $\mathrm{PbO}$ was required for fabricating monophasic $\mathrm{Pb}\left(\mathrm{Mg}_{1 / 3} \mathrm{Nb}_{2 / 3}\right) \mathrm{O}_{3}$. The morphology of calcined specimens markedly depended on the purity of $\mathrm{Pb}\left(\mathrm{Mg}_{1 / 3} \mathrm{Nb}_{2 / 3}\right) \mathrm{O}_{3}$. The grain size of $\mathrm{Pb}\left(\mathrm{Mg}_{1 / 3} \mathrm{Nb}_{2 / 3}\right) \mathrm{O}_{3}$ in the specimens containing the pyrochlore phase was $1.0-1.5 \mu \mathrm{m}$, whereas that of $\mathrm{Pb}\left(\mathrm{Mg}_{1 / 3} \mathrm{Nb}_{2 / 3}\right) \mathrm{O}_{3}$ in the pure specimens increased considerably to $6.0-10.0 \mu \mathrm{m}$. The above phenomena suggested that the coarsening of $\mathrm{Pb}\left(\mathrm{Mg}_{1 / 3} \mathrm{Nb}_{2 / 3}\right) \mathrm{O}_{3}$ was hindered by the presence of the pyrochlore phase.
\end{abstract}

Keywords: Lead magnesium niobate; Ferroelectric; Perovskite; Pyrochlore phase; Preparation; Microstructure; Solid-state reaction

\section{Introduction}

Lead magnesium niobate $\mathrm{Pb}\left(\mathrm{Mg}_{1 / 3} \mathrm{Nb}_{2 / 3}\right) \mathrm{O}_{3}$, a ferroelectric ceramic exhibiting a perovskite structure, has been intensively studied recently. Because of its high permittivity and diffuse phase transition characteristics, $\mathrm{Pb}\left(\mathrm{Mg}_{1 / 3} \mathrm{Nb}_{2 / 3}\right) \mathrm{O}_{3}$ has been recognized as one of the most potential materials for possible use in multilayer capacitors [1-3]. It is also an important material used in actuators in view of its large electrostrictivity $[4,5]$. However, the major problem in the fabrication of $\mathrm{Pb}\left(\mathrm{Mg}_{1 / 3} \mathrm{Nb}_{2 / 3}\right) \mathrm{O}_{3}$ is that the pure perovskite compound is difficult to obtain. The parasitic pyrochlore phases are often

\footnotetext{
${ }^{*}$ Corresponding author.
}

formed with $\mathrm{Pb}\left(\mathrm{Mg}_{1 / 3} \mathrm{Nb}_{2 / 3}\right) \mathrm{O}_{3}$. Due to the low dielectric permittivities of the pyrochlore phases, the dielectric permittivities of ceramics are greatly reduced by the presence of the pyrochlore phases.

In order to eliminate the pyrochlore phases, several synthesis processes have been investigated. The columbite process [6,7], using pre-reacted $\mathrm{MgNb}_{2} \mathrm{O}_{6}$ precursors, has been known to be an effective solidstate reaction process for synthesizing $\mathrm{Pb}$ $\left(\mathrm{Mg}_{1 / 3} \mathrm{Nb}_{2 / 3}\right) \mathrm{O}_{3}$. Other solution routes such as precipitation [8,9], sol-gel $[10,11]$, molten-salt $[12,13]$, and hydrothermal [14] processes have also been studied. The composition in the starting materials has been found to significantly affect the formation of $\mathrm{Pb}\left(\mathrm{Mg}_{1 / 3} \mathrm{Nb}_{2 / 3}\right) \mathrm{O}_{3}$. Adding excess $\mathrm{MgO}$ in the columbite process $[6,15]$, and adding excess $\mathrm{PbO}$ in the mixed-oxide process [16] and the molten-salt 
process [12], can increase the yield of $\mathrm{Pb}$ $\left(\mathrm{Mg}_{1 / 3} \mathrm{Nb}_{2 / 3}\right) \mathrm{O}_{3}$. Varying the ratio of all constituent species to a specific region can also facilitate the formation of $\mathrm{Pb}\left(\mathrm{Mg}_{1 / 3} \mathrm{Nb}_{2 / 3}\right) \mathrm{O}_{3}$ [17]. Although the nearly pure $\mathrm{Pb}\left(\mathrm{Mg}_{1 / 3} \mathrm{Nb}_{2 / 3}\right) \mathrm{O}_{3}$ can be obtained through the above processes, the effects of adding excess $\mathrm{MgO}$ and $\mathrm{PbO}$ on the phase formation and microstructure in the mixed-oxide process have not been thoroughly investigated. Furthermore, considering the mass production in industry, it is necessary to develop an alternative method without employing environment-sensitive materials and complicated operation processes such as in solution routes.

The main purpose of this study was to prepare monophasic $\mathrm{Pb}\left(\mathrm{Mg}_{1 / 3} \mathrm{Nb}_{2 / 3}\right) \mathrm{O}_{3}$ via the conventional mixed-oxide process without using $\mathrm{MgNb}_{2} \mathrm{O}_{6}$ precursors. For enhancing the formation of $\mathrm{Pb}\left(\mathrm{Mg}_{1 / 3} \mathrm{Nb}_{2 / 3}\right) \mathrm{O}_{3}$, excess $\mathrm{MgO}$ and $\mathrm{PbO}$ (up to 20 mol\%) were added in starting materials. The effects of both excess $\mathrm{MgO}$ and $\mathrm{PbO}$ on the phase formation were systematically investigated, and the compositional region for forming pure $\mathrm{Pb}\left(\mathrm{Mg}_{1 / 3} \mathrm{Nb}_{2 / 3}\right) \mathrm{O}_{3}$ was determined. Furthermore, the effect of the $\mathrm{Pb}\left(\mathrm{Mg}_{1 / 3} \mathrm{Nb}_{2 / 3}\right) \mathrm{O}_{3}$ purity on microstructure was examined.

\section{Experimental}

Reagent-grade $\mathrm{PbO}, \mathrm{MgO}$ and $\mathrm{Nb}_{2} \mathrm{O}_{5}$ were used as raw materials. For accurately calculating the weight of $\mathrm{MgO}$, the purchased $\mathrm{MgO}$ powder was pre-heated at $800^{\circ} \mathrm{C}$ for 30 min to eliminate $\mathrm{CO}_{2}$ and $\mathrm{H}_{2} \mathrm{O}$ absorbed on particle surfaces. 5-20 mol\% excess $\mathrm{PbO}$ and $\mathrm{MgO}$ were added in the starting materials. Weighed according to the designed composition, the starting materials were ball-milled for $48 \mathrm{~h}$ with ethyl alcohol using zirconia balls. Following drying in a rotary evaporator under reduced pressure, the mixed powder was uniaxially pressed into pellets under $196 \mathrm{MPa}$. The average packing density of the pellets was around $4.1 \mathrm{~g} / \mathrm{cm}^{3}$. Then the pressed pellets were heated at temperatures ranging from 900 to $1100^{\circ} \mathrm{C}$ for $4 \mathrm{~h}$. X-ray powder diffraction (XRD) analysis was used to identify the compounds present in the specimens. Scanning electron microscopy (SEM) was utilized to analyze the microstructural evolution of perovskite and pyrochlore phases. The content of $\mathrm{Pb}\left(\mathrm{Mg}_{1 / 3} \mathrm{Nb}_{2 / 3}\right) \mathrm{O}_{3}$ was calculated from the intensity of the XRD peaks according to the following formula:

$$
\begin{aligned}
& \text { Content of } \mathrm{Pb}\left(\mathrm{Mg}_{1 / 3} \mathrm{Nb}_{2 / 3}\right) \mathrm{O}_{3}(\%) \\
& =\frac{I_{\mathrm{Pb}\left(\mathrm{Mg}_{1 / 3} \mathrm{Nb}_{2 / 3)} \mathrm{O}_{3}(110)\right.}}{I_{\mathrm{Pb}\left(\mathrm{Mg}_{1 / 3} \mathrm{Nb}_{2 / 3}\right) \mathrm{O}_{3}(110)}+I_{\text {pyrochlore (222) }}} .
\end{aligned}
$$

\section{Results and discussion}

Fig. 1 shows the contents of $\mathrm{Pb}\left(\mathrm{Mg}_{1 / 3} \mathrm{Nb}_{2 / 3}\right) \mathrm{O}_{3}$ at various calcination temperatures when 5-20 mol\% excess $\mathrm{MgO}$ was added in the starting materials. At $900^{\circ} \mathrm{C}$, a large amount of $\mathrm{Pb}\left(\mathrm{Mg}_{1 / 3} \mathrm{Nb}_{2 / 3}\right) \mathrm{O}_{3}$ was formed with pyrochlore phase. The content of $\mathrm{Pb}\left(\mathrm{Mg}_{1 / 3} \mathrm{Nb}_{2 / 3}\right) \mathrm{O}_{3}$ for all compositions increased after $1000^{\circ} \mathrm{C}$ calcination. However, the content of $\mathrm{Pb}\left(\mathrm{Mg}_{1 / 3} \mathrm{Nb}_{2 / 3}\right) \mathrm{O}_{3}$ dropped at $1100^{\circ} \mathrm{C}$, indicating that the decomposition of $\mathrm{Pb}\left(\mathrm{Mg}_{1 / 3} \mathrm{Nb}_{2 / 3}\right) \mathrm{O}_{3} \mathrm{oc}-$ curred at elevated temperatures. The amount of $\mathrm{MgO}$ was found to significantly influence the formation and decomposition processes of $\mathrm{Pb}\left(\mathrm{Mg}_{1 / 3} \mathrm{Nb}_{2 / 3}\right) \mathrm{O}_{3}$. At temperatures lower than $1000^{\circ} \mathrm{C}$, increasing the amount of excess $\mathrm{MgO}$ tended to facilitate the formation of $\mathrm{Pb}\left(\mathrm{Mg}_{1 / 3} \mathrm{Nb}_{2 / 3}\right) \mathrm{O}_{3}$. However, at elevated temperatures, the more excess $\mathrm{MgO}$ was added, the

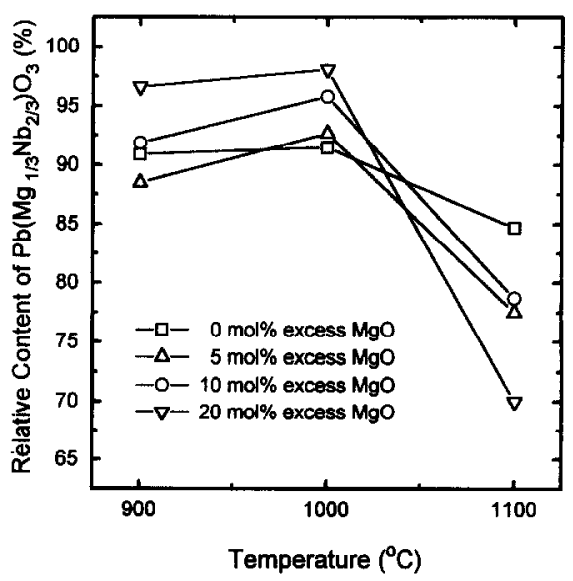

Fig. 1. Relative content of $\mathrm{Pb}\left(\mathrm{Mg}_{1 / 3} \mathrm{Nb}_{2 / 3}\right) \mathrm{O}_{3}$ versus calcination temperature for the specimens with various amounts of excess $\mathrm{MgO}$. 


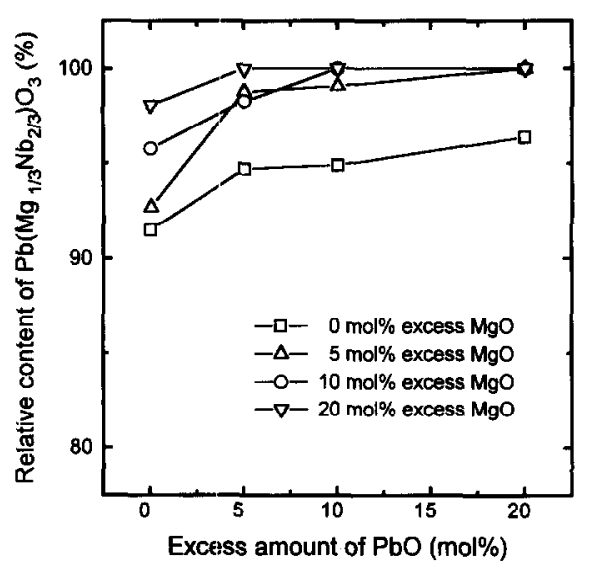

Fig. 2. The relation between the content of $\mathrm{Pb}\left(\mathrm{Mg}_{1 / 3} \mathrm{Nb}_{2 / 3}\right) \mathrm{O}_{3}$ and various amounts of excess $\mathrm{PbO}$ and $\mathrm{MgO}$.

less $\mathrm{Pb}\left(\mathrm{Mg}_{1 / 3} \mathrm{Nb}_{2 / 3}\right) \mathrm{O}_{3}$ was formed, implying that the thermal stability of $\mathrm{Pb}\left(\mathrm{Mg}_{1 / 3} \mathrm{Nb}_{2 / 3}\right) \mathrm{O}_{3}$ was reduced.

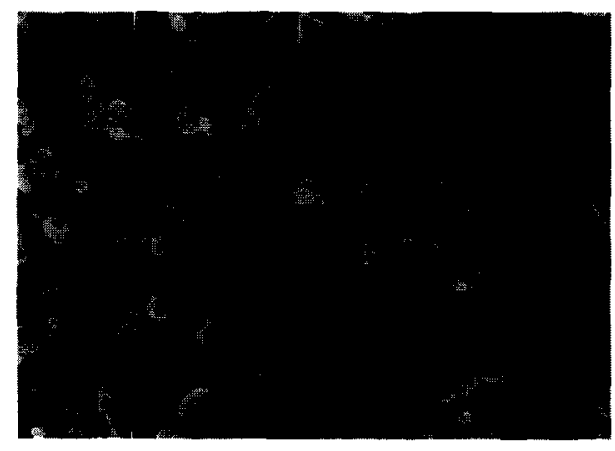

(a)

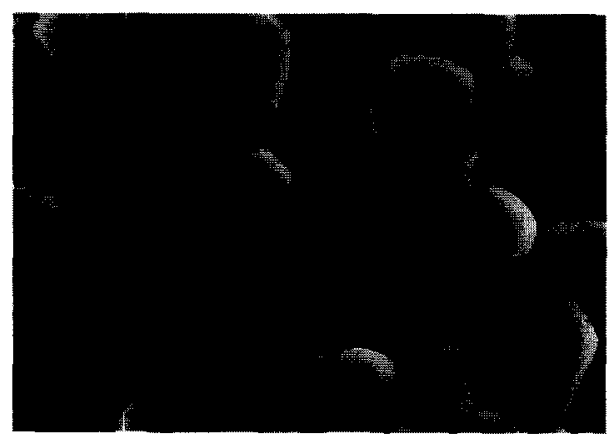

(c)

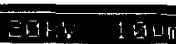

As shown in Fig. 1 , the calcination at $1000^{\circ} \mathrm{C}$ was found to be the optimum condition for $\mathrm{Pb}$ $\left(\mathrm{Mg}_{1 / 3} \mathrm{Nb}_{2 / 3}\right) \mathrm{O}_{3}$ to form. However, pure $\mathrm{Pb}$ $\left(\mathrm{Mg}_{1 / 3} \mathrm{Nb}_{2 / 3}\right) \mathrm{O}_{3}$ could not be synthesized by merely adding excess $\mathrm{MgO}$. Therefore the effects of both excess $\mathrm{MgO}$ and $\mathrm{PbO}$ on the phase formation were examined. The relation between the content of $\mathrm{Pb}\left(\mathrm{Mg}_{1 / 3} \mathrm{Nb}_{2 / 3}\right) \mathrm{O}_{3}$ and the amounts of excess $\mathrm{MgO}$ and $\mathrm{PbO}$ is indicated in Fig. 2. The contents of the $\mathrm{Pb}\left(\mathrm{Mg}_{1 / 3} \mathrm{Nb}_{2 / 3}\right) \mathrm{O}_{3}$ for each designed composition are listed in Table 1. When a fixed amount of excess $\mathrm{PbO}$ was added in the starting materials, increasing the $\mathrm{MgO}$ amount significantly raised the amount of $\mathrm{Pb}\left(\mathrm{Mg}_{1 / 3} \mathrm{Nb}_{2 / 3}\right) \mathrm{O}_{3}$ formed. As for a fixed amount of $\mathrm{MgO}$ in the starting materials, increasing the $\mathrm{PbO}$ amount also increased the yield of $\mathrm{Pb}$ $\left(\mathrm{Mg}_{1 / 3} \mathrm{Nb}_{2 / 3}\right) \mathrm{O}_{3}$. As seen in Table 1 , the suitable conditions for pure $\mathrm{Pb}\left(\mathrm{Mg}_{1 / 3} \mathrm{Nb}_{2 / 3}\right) \mathrm{O}_{3}$ to form lie in the region where both excess $\mathrm{MgO}$ and $\mathrm{PbO}$ were
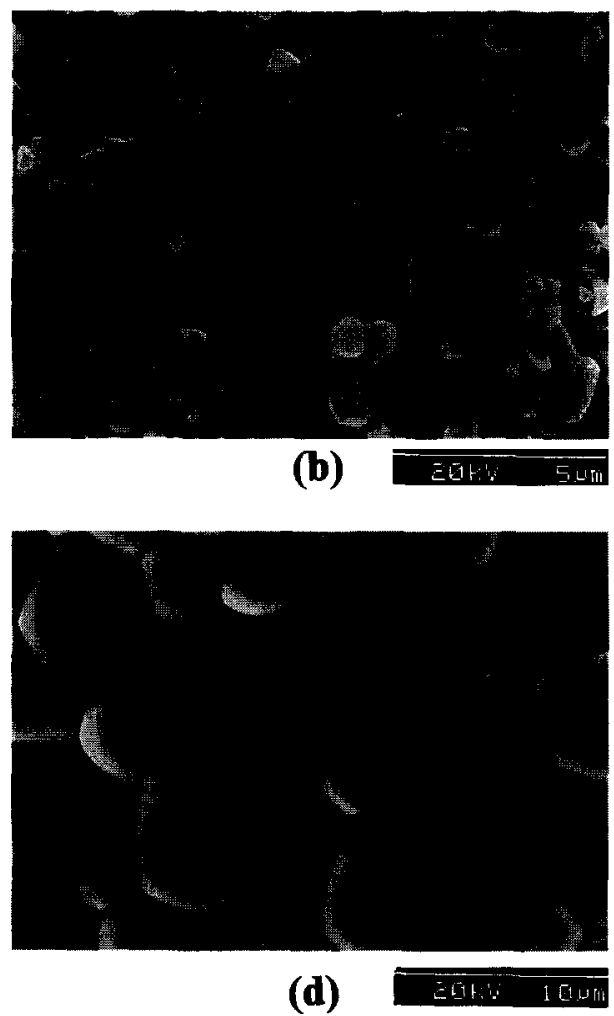

(d)

Fig. 3. Microstructures of $1000^{\circ} \mathrm{C}$ calcined specimens containing excess amounts of constituent compounds for (a) $5 \mathrm{~mol} \% \mathrm{PbO}$ and 0 mol\% $\mathrm{MgO}$, (b) $5 \mathrm{~mol} \% \mathrm{PbO}$ and $5 \mathrm{~mol} \% \mathrm{MgO}$, (c) $10 \mathrm{~mol} \% \mathrm{PbO}$ and $10 \mathrm{~mol} \% \mathrm{MgO}$, and (d) $20 \mathrm{~mol} \% \mathrm{PbO}$ and $5 \mathrm{~mol} \% \mathrm{MgO}$. 
Table 1

Relative content (in \%) of $\mathrm{Pb}\left(\mathrm{Mg}_{1 / 3} \mathrm{Nb}_{2 / 3}\right) \mathrm{O}_{3}$ versus various amounts of excess $\mathrm{MgO}$ and $\mathrm{PbO}$ after $1000^{\circ} \mathrm{C}$ calcination

\begin{tabular}{lcrcr}
\hline $\begin{array}{l}\text { Excess amount } \\
\text { of } \mathrm{MgO}(\mathrm{mol} \%)\end{array}$ & \multicolumn{4}{c}{ Excess amount of $\mathrm{PbO}(\mathrm{mol} \%)$} \\
\cline { 2 - 5 } & \multicolumn{1}{c}{0} & \multicolumn{1}{c}{5} & \multicolumn{1}{c}{10} & \multicolumn{1}{c}{20} \\
\hline 0 & 91.5 & 94.7 & 94.9 & 96.4 \\
5 & 92.7 & 98.8 & 99.1 & 100.0 \\
10 & 95.8 & 98.3 & 100.0 & 100.0 \\
20 & 98.1 & 100.0 & 100.0 & 100.0 \\
\hline
\end{tabular}

added. When the excess amount of $\mathrm{MgO}$ was 5,10 and $20 \mathrm{~mol} \%$, the minimum excess amount of $\mathrm{PbO}$ required for synthesizing pure $\mathrm{Pb}\left(\mathrm{Mg}_{1 / 3} \mathrm{Nb}_{2 / 3}\right) \mathrm{O}_{3}$ was 20,10 and $5 \mathrm{~mol} \%$, respectively. The results indicate that as more $\mathrm{MgO}$ was added, less $\mathrm{PbO}$ was needed for the synthesis of monophasic $\mathrm{Pb}$ $\left(\mathrm{Mg}_{1 / 3} \mathrm{Nb}_{2 / 3}\right) \mathrm{O}_{3}$, and vice versa.

For realizing the formation reaction of $\mathrm{Pb}\left(\mathrm{Mg}_{1 / 3} \mathrm{Nb}_{2 / 3}\right) \mathrm{O}_{3}$, three kinds of specimens were quenched at various temperatures during heating. The amounts of excess $\mathrm{PbO}$ in specimens $\mathrm{A}, \mathrm{B}$ and $\mathrm{C}$ were 0,10 , and $20 \mathrm{~mol} \%$, respectively, and the amount of excess $\mathrm{MgO}$ in all specimens was 10 mol\%. At $800^{\circ} \mathrm{C}$ unreacted $\mathrm{PbO}$ was found to coexist with the pyrochlore phase and a small amount of $\mathrm{Pb}\left(\mathrm{Mg}_{1 / 3} \mathrm{Nb}_{2 / 3}\right) \mathrm{O}_{3}$ in all specimens. When the temperature reached $900^{\circ} \mathrm{C}$, the content of $\mathrm{Pb}$ $\left(\mathrm{Mg}_{1 / 3} \mathrm{Nb}_{2 / 3}\right) \mathrm{O}_{3}$ increased rapidly, and all unreacted $\mathrm{PbO}$ disappeared. On further heating to $1000^{\circ} \mathrm{C}$, the formation rate of $\mathrm{Pb}\left(\mathrm{Mg}_{1 / 3} \mathrm{Nb}_{2 / 3}\right) \mathrm{O}_{3}$ levelled off. Compared with specimen A, specimens B and C had a larger amount of unreacted $\mathrm{PbO}$ at $800^{\circ} \mathrm{C}$, and a larger amount of $\mathrm{Pb}\left(\mathrm{Mg}_{1 / 3} \mathrm{Nb}_{2 / 3}\right) \mathrm{O}_{3}$ after $900^{\circ} \mathrm{C}$ heating. Considering that the melting of $\mathrm{PbO}$ occurs at $888^{\circ} \mathrm{C}$, the formation process of $\mathrm{Pb}\left(\mathrm{Mg}_{1 / 3^{-}}\right.$ $\left.\mathrm{Nb}_{2 / 3}\right) \mathrm{O}_{3}$ seems to be accelerated by the melting of the unreacted $\mathrm{PbO}$ on heating from 800 to $900^{\circ} \mathrm{C}$. Without the presence of the molten $\mathrm{PbO}$, the conversion of the pyrochlore phase to the perovskite phase becomes slow on further heating from 900 to $1000^{\circ} \mathrm{C}$.

The microstructures of the $1000^{\circ} \mathrm{C}$-calcined specimens were found to strongly depend on the purity of $\mathrm{Pb}\left(\mathrm{Mg}_{1 / 3} \mathrm{Nb}_{2 / 3}\right) \mathrm{O}_{3}$. When $\mathrm{Pb}\left(\mathrm{Mg}_{1 / 3} \mathrm{Nb}_{2 / 3}\right) \mathrm{O}_{3}$ coexisted with the pyrochlore phase, two kinds of grains with different morphology were observed. These specimens contained the rounded $\mathrm{Pb}$ $\left(\mathrm{Mg}_{1 / 3} \mathrm{Nb}_{2 / 3}\right) \mathrm{O}_{3}$ grains with a size of $1.0-1.5 \mu \mathrm{m}$ and the polyhedral pyrochlore grains with submicron size (as seen in Fig. 3a and 3b). On the other hand, when pure $\mathrm{Pb}\left(\mathrm{Mg}_{1 / 3} \mathrm{Nb}_{2 / 3}\right) \mathrm{O}_{3}$ was formed, all polyhedral grains disappeared, and the grain size of $\mathrm{Pb}\left(\mathrm{Mg}_{1 / 3} \mathrm{Nb}_{2 / 3}\right) \mathrm{O}_{3}$ markedly increased to $6.0-10.0$ $\mu \mathrm{m}$ (as seen in Fig. $3 \mathrm{c}$ and $3 \mathrm{~d}$ ). From the above microstructural evolution, it is considered that the coarsening of $\mathrm{Pb}\left(\mathrm{Mg}_{1 / 3} \mathrm{Nb}_{2 / 3}\right) \mathrm{O}_{3}$ grains seems to be retarded by the presence of the pyrochlore phase in the matrix. As a result, the addition of excess $\mathrm{MgO}$ and $\mathrm{PbO}$ in the mixed-oxide process significantly affects not only the formation reaction, but also the microstructure of $\mathrm{Pb}\left(\mathrm{Mg}_{1 / 3} \mathrm{Nb}_{2 / 3}\right) \mathrm{O}_{3}$.

\section{Conclusion}

(i) Pyrochlore-free $\mathrm{Pb}\left(\mathrm{Mg}_{1 / 3} \mathrm{Nb}_{2 / 3}\right) \mathrm{O}_{3}$ was successfully synthesized by the mixed-oxide process via adding both excess $\mathrm{MgO}$ and $\mathrm{PbO}$. When the excess amount of $\mathrm{MgO}$ was increased, the minimum excess amount of $\mathrm{PbO}$ required for fabricating pure $\mathrm{Pb}\left(\mathrm{Mg}_{1 / 3} \mathrm{Nb}_{2 / 3}\right) \mathrm{O}_{3}$ was reduced.

(ii) The optimum calcination temperature for the $\mathrm{Pb}\left(\mathrm{Mg}_{1 / 3} \mathrm{Nb}_{2 / 3}\right) \mathrm{O}_{3}$ formation was found to be $1000^{\circ} \mathrm{C}$. Heating at higher temperatures caused $\mathrm{Pb}\left(\mathrm{Mg}_{1 / 3} \mathrm{Nb}_{2 / 3}\right) \mathrm{O}_{3}$ to decompose.

(iii) In the biphasic specimens, the $\mathrm{Pb}\left(\mathrm{Mg}_{1 / 3^{-}}\right.$ $\left.\mathrm{Nb}_{2 / 3}\right) \mathrm{O}_{3}$ grains, $1.0-1.5 \mu \mathrm{m}$ in size, coexist with the polyhedral pyrochlore-phase grains. As for pure $\mathrm{Pb}\left(\mathrm{Mg}_{1 / 3} \mathrm{Nb}_{2 / 3}\right) \mathrm{O}_{3}$, the grain size of it was markedly increased to $6.0-10.0 \mu \mathrm{m}$. The above phenomena imply that the presence of the pyrochlore phase could hinder the coarsening of the $\mathrm{Pb}\left(\mathrm{Mg}_{1 / 3^{-}}\right.$ $\left.\mathrm{Nb}_{2 / 3}\right) \mathrm{O}_{3}$ grains.

\section{References}

[1] J.P. Guha, D.J. Hong and H.U. Anderson, J. Am. Ceram. Soc. 71 (1988) C152.

[2] M.F. Yan, H.C. Ling and W.W. Rhodes, J. Mater. Res. 4 (1989) 945.

[3] P. Papet, J.P. Dougherty and T.R. Shrout, J. Mater. Res. 5 (1990) 2902.

[4] K. Uchino, S. Nomura, L.E. Cross, S.J. Jang and R.E. Newnham, J. Appl. Phys. 51 (1980) 1142.

[5] K. Uchino, Am. Ceram. Soc. Bull. 65 (1986) 647.

[6] S.L. Swartz and T.R. Shrout, Mater. Res. Bull. 18 (1982) 662. 
[7] C.H. Lu and J.T. Lee, J. Ceram. Soc. Japan, in press.

[8] A. Watanabe, H. Haneda, Y. Moriyoshi, S. Shirasaki, S. Kuramoto and H. Yamamura, J. Mater. Sci. 27 (1992) 1245.

[9] G. Guzman, M.A. Asegerter, P. Barboux and J. Livage, J. Mater. Sci. 28 (1993) 6510.

[10] F. Chaput, J.P. Boilot, M. Lejeune, R. Papiernik and L.G. Hubert-Pfalzgraf, J. Am. Ceram. Soc. 72 (1989) 1335.

[11] L.P. Francis, Y.J. $\mathrm{OH}$ and D.A. Payne, J. Mater. Sci, 25 (1990) 5007.

[12] H. Katayama, M. Abe,and T. Akiba, Ceram. Inter. 15 (1989) 289.
[13] K.H. Yoon, Y.S. Cho, D.H. Lee and D.H. Kang, J. Am. Ceram. Soc. 76 (1993) 1373.

[14] K. Yanagisawa, J. Mater. Sci. Letters 12 (1993) 1842.

[15] H.C. Wang and W.A. Schulze, J. Am. Ceram. Soc. 73 (1990) 825.

[16] M. Lejeune and J.P. Boilot, Am. Ceram. Soc. Bull. 64 (1985) 679.

[17] M.F. Yan, H.C. Ling and W.W. Rhodes, J. Mater. Res. 4 (1989) 930. 